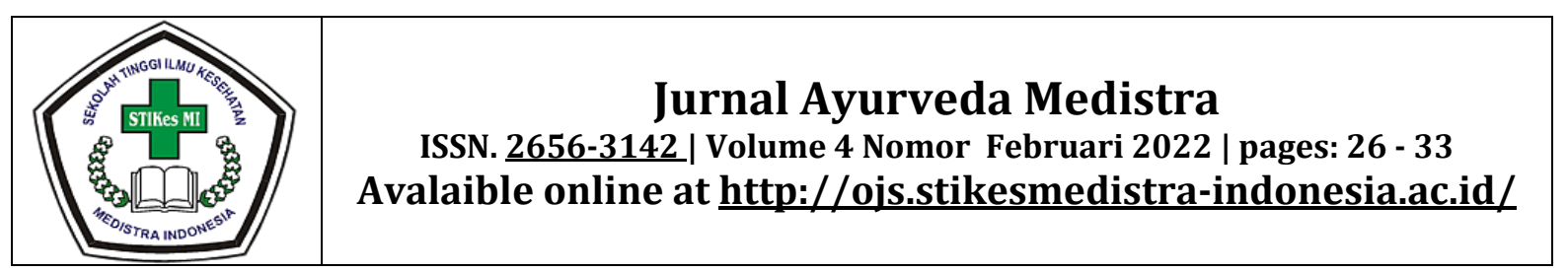

\title{
Identifikasi Senyawa Anti Mikroba Ekstrak Etanol Batang Brotowali (Tinospra Crispa (L.) \\ Terhadap Staphylococcus Aureus, Bacillus Substillis, Dan Candida Albicans Dengan Metode KIt Bioautografi
}

\author{
Dra. Apt, Nunung Nurhayati, M.Farm Dharma Yanti,S.Pd, M.Farm
}

Program Studi Farmasi (S1) STIKes Medistra Indonesia nunung6274@gmail.com, dharmayantilukman@gmail.com 085709252433

\begin{abstract}
ABSTRAK
Tanaman brotowali (Tinospra crispa (L.) secara empiris telah digunakan untuk penyakit seperti penurun panas, penghilang sakit, menurunkan kadar gula dan sebagai obat luar untuk luka dan gatal - gatal. Batang brotowali dilaporkan dipakai untuk mengobati penyakit infeksi karena mengandung senyawa flavonoid, saponin, tanin, glikosida. Penelitian ini bertujuan untuk mengidentifikasi perkiraan senyawa yang memiliki aktivitas anti mikroba dengan metode bioautografi, GCMS dan spektrofotometri infra merah. Ekstraksi dilakukan dengan pelarut etanol $96 \%$ dengan metode maserasi dan di partisi menggunakan $n$-heksan dan etil asetat. Aktivitas anti mikroba diuji pada ekstrak etanol $96 \%$, fraksi $n$-heksan dan fraksi etil asetat dilakukan menggunakan metode difusi kertas cakram terhadap mikroba Staphylococcus aureus, Bacillus substillis, dan Candida albicans. Hasil yang diperoleh menunjukan bahwa ekstrak etanol $96 \%$, fraksi heksan dan fraksi air tidak menunjukan aktivitas anti bakteri. Hasil KLT fraksi etil asetat menghasilkan 4 bercak dengan diameter daerah hambat terbesar terhadap mikroba sehingga pengujian fraksi $n$-heksan dilanjutkan dengan metode bioautografi. Uji bioautografi menunjukan bahwa aktivitas anti mikroba terlihat pada hrf 42,8 , kemudian ekstrak dianalisa dengan spektrofotometri infra merah dan GCMS. Analisa dengan spektrofotometri infra merah menunjukan adanya gugus-gugus fungsional $\mathrm{C}=\mathrm{O}, \mathrm{CH}$ stretch, alkena $(\mathrm{C}=\mathrm{C}), \mathrm{OH}$. Hasil analisa dengan GCMS dan prediksi identitas puncak-puncak yang diperoleh menggunakan database menunjukan bahwa puncak terbesar adalah octanoic acid, 4 hydroxy-3-methoxy vanillin, phenol, 2,4 bis(1,1-dimethyl ethyl, 2 pentadecanon, $n$-hexadecanoic palmitic acid. Menurut pustaka senyawa 4 hydroxy-3 methoxy vanillin dan palmitic acid dilaporkan memiliki aktivitas antimikroba.
\end{abstract}

Kata kunci : Tinospora crispa L, etil asetat, anti mikroba, KLT Bioautografi, spectrofotometri IR, GCMS.

\section{ABSTRACT}

The brotowali plant (Tinospra crispa (L.) has empirically been used for diseases such as fever, pain relief, lowering sugar levels and as an external medicine for wounds and itching. Brotowali stems are reported to be used to treat infectious diseases because they contain flavonoid compounds, saponins, tannins, glycosides. This study aims to identify the approximate compounds that have antimicrobial activity using bioautography, GCMS and infrared spectrophotometry methods.

Extraction was carried out with $96 \%$ ethanol solvent by maceration method and partitioned using $n$-hexane and ethyl acetate. Antimicrobial activity was tested on $96 \%$ ethanol extract, $n$-hexane fraction and ethyl acetate fraction using the paper disc diffusion method against Staphylococcus aureus, Bacillus substillis, and Candida albicans microbes.

The results obtained showed that $96 \%$ ethanol extract, hexan fraction and water fraction did not show antibacterial activity. TLC results of the ethyl acetat fraction produced 4 spots with the largest diameter of the inhibition zone against microbes, so that the testing of the ethyl acetat fraction was continued with the bioautography method. The bioautography test showed that the antimicrobial activity was visible at hrf 42.8 , then the extract was analyzed by infrared spectrophotometry and GCMS. Analysis with infrared spectrophotometry showed the presence of functional groups $C=O, C H$ stretch, alkene $(C=C), O H$. The results of the GCMS analysis and the prediction of the identity of the peaks obtained using the database showed that the largest peak was octanoic acid, 4 hydroxy-3-methoxy vanillin, phenol, 2,4 bis(1,1-dimethyl ethyl, 2 pentadecanone, $n$-hexadecanoic). palmitic acid .According to the literature, 4 hydroxy-3 methoxy vanillin and palmitic acid were reported to have antimicrobial activity.

Keywords: Tinospora crispa L, ethyl acetat, antimicrobial, TLC Bioautography, IR spectrophotometry, GCMS. 


\section{PENDAHULUAN}

Salah satu tanaman yang dapat digunakan sebagai obat infeksi kulit seperti bisul adalah Batang Brotowali (Tinospora crispa L) pada berbagai literatur disebutkan bahwa tanaman brotowali, khususnya bagian batang dapat digunakan untuk pengobatan berbagai penyakit infeksi. Tanaman in diketahui mengandung saponin, tanin, alkoloid, glikosida dan berberin. [1]

Flavonoid merupakan golongan senyawa fenol alam. Fenol diduga dapat berfungsi sebaga antimikroba karena mendenaturasi protein dan merusak membran sel, sedangkan mekanisme penghambatan saponin terhadap mikroba belum diketahui secara jelas.[2] Berdasarkan hal tersebut maka akan dilakukan penelitian mengenai aktivitas antimikroba ekstrak Batang Brotowali (Tinospora crispa L) secara in vitro dengan harapan dapat membuktikan kebenaran informasi tentang aktifitas antimikroba ekstrak etanol, ekstrak heksan dan ektrak etil asetat Batang Brotowali (Tinospora crispa L) terhadap bakteri Staphyloccocus aureus, Bacillus substillis dan Candida albicans dengan metoda difusi cakram, Ekstrak dengan aktivitas antibakteri terbaik berdasarkan metode difusi cakram lalu di identifikasi menggunakan kromatografi lapis tipis dengan cara bioautografi [3] yaitu dengan menempelkan langsung kromatogram yang berisi ekstrak uji pada media yang terinokulasi dengan mikroba uji. Identitas senyawa antimikroba pada kromatogram tersebut dianalisis dengan menggunakan GCMS dan Spektrofotometri infra merah

\section{METODE PENELITIAN}

Tahap preparasi sampel meliputi ekstraksi sampe sehingga diperoleh ekstrak pekat. Tahap analisis sampel meliputi uji aktivitas mikroba dengan metode difusi cakram,uji KLT, uji bioautografi, analisis kualitatif dengan GCMS dan Spektrofotometri Infra merah.

CARA KERJA

Preparasi Sampel :

1. Ekstraksi Sampel

Simplisia kering ditimbang sebanyak 1 kilogram lalu dimasukkan ke toples kaca Ditambahkan etanol teknis sebanyak $1500 \mathrm{ml}$, dimaserasi hasil ekstraksi disaring filtratnya ditampung dalam botol kaca. Proses ekstraksi dilakukan sebanyak 3 kali maserasi. Filtrat yang dikumpulkan di keringkan dengan menggunakan rotary evaporator dan penangas air.

2. Partisi Ekstrak

Ekstrak etanol pekat yang diperoleh dipartis dengan air, haksan dan etil asetat. Sehingga diperoleh ekstrak partisi polar (air), ekstrak partisi semi polar (etil asetat) dan ekstrak partisi non polar (heksan)

\section{Penapisan fitokimia}

Dilakukan terhadap ektrak etanol kental untuk mengidentifikasi senyawa kimia yang terkandung ke dalam bahan yang digunakan

4. Uji daya antimikroba ekstrak batang brotowali terhadap bakteri Staphylococcus aureus, Bacillus subtillis, dan Candida albicans

a. Sterilisasi

Persiapan awal untuk uji antimikroba:

1) Sterilisasi dengan autoklaf Media dan pereaksi disterilkan pada suhu $121^{\circ} \mathrm{C}$ selama 15 menit

2) Sterilisasi dengan oven Suhu yang digunakan $150-170^{\circ} \mathrm{C}$ selama 1 jam, untuk alat seperti cawan Petri, Erlemeyer, tabung reaksi, Beaker, gelas ukur dan pipet volum.

3) Sterilisasi dengan api bunsen (tehnik aseptis)

Untuk alat seperti jarum ose pinset dan mulut tabung reaksi dilakukan dengan cara memanaskan alat tersebut diatas api Bunsen langsung selama beberapa saat diamkan sebentar sebelum digunakan.

b. Penyiapan mikroba uji

1) Pembuatan Media agar miring

Media pembenihan menggunakan Nutrien Agar (NA)dibuat dengan cara melarutkan 28 gr NA kedalam 1 liter air suling kemudian dipanaskan sampai larut, sterilkan pada suhu $121^{\circ} \mathrm{C}$ selama 15 menit. Kemudian dituangkan kedalam beberapa tabung reaksi steril dan dimiringkan, diamkan sampai membeku (disebut media agar miring).

2) Pembiakan bakteri (Regenerasi Mikroba)

Ambil satu sengkelit bakteri dari biakan murni Staphylococcus aureus, Bacillus subtillis, dan Candida albicans dengan menggunakan ujung ose steril, masukkan kedalam tabung reaksi berisi media agar miring (Nutrien agar) dengan cara menggoreskan secara zig-zag diseluruh lempeng secara merata, kemudian diinkubasi pada suhu $37^{\circ} \mathrm{C}$ selama 24 jam.

c. Uji aktivitas antibakteri sampel (ekstrak etanol batang brotowali)

Ekstrak etanol batang brotowali yang dipartisi dengan $n$-heksan, etil asetat dan air dilakukan uji aktivitas antibakterinya terhadap Staphylococcus aureus, Bacillus subtillis dan Candida albicans dengan metode difusi cakram. Prosedur Kerja:

1. Masukkan $500 \mu$ l suspensi bakteri Staphylococcus aureus dengan menggunakan mikropipet, kedalam cawan Petri steril.

2. Tambahkan $20 \mathrm{ml}$ Nutrien agar (NA), kemudian diratakan dengan spreader, biarkan sampai membeku.

Kedalam cawan Petri media agar yang sudah dingin(beku), dibagi 4 bagian, letakkan kertas cakram steril menggunakan ujung mikro pipet, tekan dengan pinset steril agar kertas cakram benar-benar menempel pada media agar.

3. Masukan masing-masing $20 \mu \mathrm{l}$ larutan ekstrak etanol batang brotowali ( dengan konsentrasi $10 \%, \quad 5 \%, 2,5 \%$, dan $1,25 \%$ dengan penotolan pada kertas cakram menggunakan mikro pipet dan dilakukan secara triplo.

4. Inkubasi pada suhu $37^{\circ} \mathrm{C}$ selama 24jam. 
5. Hal yang sama dilakukan terhadap larutan uji fase $n$ heksan, fase etil asetat, dan fase air.

6. Hal yang sama juga dilakukan uji antibakteri Basillus subtillis, dan Candida albicans[5]

d. Uji aktivitas antibakteri standar streptomisin

Prosedur kerja

1. Masukkan $500 \mu$ l suspensi bakteri dengan menggunakan mikropipet, kedalam cawan petri steril.

2. Tambahkan $20 \mathrm{ml}$ Nutrien agar (NA), kemudian diratakan dengan spreader, biarkan sampai memadat.

3. Kedalam cawan petri media agar yang sudah memadat, dibagi 4 bagian, letakkan kertas cakram steril menggunakan ujung mikro pipet, tekan dengan pinset steril agar kertas cakram benar-benar menempel pada media agar.

4. Masukan masing-masing $10 \mu \mathrm{l}$ larutan streptomisin ( dengan konsentrasi $1 \%, 0,5 \%, 0,25 \%$, dan $0,125 \%$ dengan penotolan pada kertas cakram menggunakan mikro pipet, pengerjaan dilakukan dengan triplo.

5. Inkubasi pada suhu $30^{\circ} \mathrm{C}$ selama 24 jam. Efektifitas antibakteri dinyatakan efektif, apabila disekitar kertas cakram terdapat zona bening, zona hambat diukur dengan jangka sorong, kemudian dicatat hasilnya.[5]

e. Uji aktifitas antibakteri fase etil asetat batang brotowali dengan metode Bioautografi [3]

Metode bioautografi adalah metode untuk menunjukkan adanya aktivitas antibakteri dari suatu zat. Metode in merupakan penggabungan tehnik kromatografi lapis tipis dengan respon dari mikroorganisme. Prinsip metode ini adalah menempelkan langsung kromatogram yang ditampakkan bercaknya dan diukur hRf nya pada media yang telah terinokulasi bakteri uji, kemudian media tersebut diinkubasi dalam jangka waktu tertentu dan amati hambatannya. Prosedur kerja:

1. Bejana KLT dijenuhkan dengan eluen menggunakan kertas saring

2. Siapkan lempeng KLT berukuran $2 \mathrm{x} 10 \mathrm{~cm}$, kemudian ditanda dengan batas bawah dengan jarak $1,5 \mathrm{~cm}$ dari tepi bawah pla $\mathrm{KLT}$ dan batas atas dengan jarak $1 \mathrm{~cm}$ tepi atas, kemudian aktifkan plat KLT dalam oven dengan suhu $40^{\circ} \mathrm{C}$ selama $10-15$ menit.

3. Ekstrak fase etil asetat batang brotowali dtotolkan berbentuk garis sebanyak $20 \mu \mathrm{l}$ dengan menggunakan pipa kapiler.

4. Plat KLT dimasukkan kedalam bejana yang telah jenuh yang sudah dmasukkan eluen (fase gerak), elusi sampai batas atas ditandai dengan adanya bercak komponen senyawa.
5. Keluarkan plat KLT setelah proses elusi selesai, kemudian dikeringkan hingga bercak tampak dan ukur Rf nya.

6. Penyiapan agar inokula kedalam cawan Petri steril. Tuangkan $500 \mu$ suspensi mikroba uji kemudian tuangkan Nutrien agar (NA) $20 \mathrm{ml}$, digoyang-goyang agar bercampur homogen biarkan sampai memadat.

7. Letakkan plat KLT yang sudah diketahui $\mathrm{Rf}$ nya dengan posis terbalik, diamkan selama 15-30 menit, tandai posisi bercak noda pada bagian bawah cawan Petri.

8. Angkat dan keluarkan plat dari permukaan agar.

9. Inkubasi cawan Petri selama 1618 jam pada suhu $35-37^{\circ} \mathrm{C}$.

10. Amati daerah bening disekitar bercak, yang menunjukkan bahwa bercak tersebut mengandung senyawa antibakteri, dan ukur Rf nya.[3]

11. Plat KLT bercak noda berbentuk pita dikerok dan diekstraksi dengan etil asetat, ambil larutan etil asetat (lakukan 3x), diuapkan, dilanjutkan identifikasi dengan spektrofotometri infra merah (IR) dan kromatografi gas-spektrometri massa ( GCMS).

\section{HASIL DAN PEMBAHASAN}

1. Ekstrak Etanol Batang Brotowali

Ekstrak kental batang brotowali yang diperoleh adalah 148,6 gram (rendaman 14,86\%).

\section{Penapisan Fitokimia}

Hasil penapisan fitokimia yang terdapat dalam ekstrak batang brotowali sesuai seperti yang tertera pada monografi ekstrak yang terdapat pada Tabel. 1 berikut:

Tabel.1 Penapisan Fitokimia Ekstrak Etanol

\begin{tabular}{|c|c|c|c|c|}
\hline \multirow[b]{2}{*}{$\mathrm{NO}$} & \multirow[b]{2}{*}{$\begin{array}{l}\text { Uji } \\
\text { Penap } \\
\text { isan }\end{array}$} & \multirow[b]{2}{*}{ Pereaksi } & \multirow[b]{2}{*}{ Brotowali } & \multirow[b]{2}{*}{ Persyaratan } \\
\hline & & & & \\
\hline 1 & Tanin & $\mathrm{FeCl}_{3}$ & $\begin{array}{l}(+) \text { Hijau } \\
\text { kehitaman }\end{array}$ & $\begin{array}{l}\text { Warna biru tua } \\
\text { atau } \\
\text { kehitaman }\end{array}$ \\
\hline 2 & $\begin{array}{l}\text { Sapon } \\
\text { in }\end{array}$ & $\mathrm{HCl} 1 \%$ & $\begin{array}{l}(+) \\
\text { terbentuk } \\
\text { buih }\end{array}$ & $\begin{array}{l}\text { Terbentuk buih } \\
\text { dan buih tidak } \\
\text { hilang dalam } 10 \\
\text { menit }\end{array}$ \\
\hline \multirow{3}{*}{3} & \multirow{3}{*}{$\begin{array}{l}\text { Flavon } \\
\text { oid }\end{array}$} & $\begin{array}{l}\text { Seng } \\
\text { dan } \mathrm{HCl}\end{array}$ & $\begin{array}{ll}(-) & \text { biru } \\
\text { keabu } & - \\
\text { abuan } & \\
\end{array}$ & $\begin{array}{ll}\text { Warna } & \text { merah } \\
\text { (flavonoid) } & \end{array}$ \\
\hline & & $\begin{array}{l}\text { Magnesi } \\
\text { um dan } \\
\mathrm{HCl}\end{array}$ & $\begin{array}{l}\text { (+) kuning } \\
\text { jingga }\end{array}$ & $\begin{array}{lr}\text { Warna } & \text { kuning } \\
\text { jingga } & \text { (flavon, } \\
\text { kalkon dan auron) }\end{array}$ \\
\hline & & $\begin{array}{l}\text { As. } \\
\text { Borat } \\
\text { dan As. } \\
\text { Oksalat } \\
\text { kemudia } \\
\text { n eter }\end{array}$ & $\begin{array}{l}(-) \text { larutan } \\
\text { berwarna } \\
\text { merah } \\
\text { tidak } \\
\text { berfluores } \\
\text { ensi } \\
\end{array}$ & $\begin{array}{l}\text { Warna kuning } \\
\text { berfluoresensi } \\
\text { (flavonoid) }\end{array}$ \\
\hline \multirow[t]{2}{*}{4} & \multirow{2}{*}{$\begin{array}{l}\text { Alkaloi } \\
\quad \mathrm{d}\end{array}$} & Meyer & $\begin{array}{l}(+) \\
\text { endapan } \\
\text { warna } \\
\text { putih }\end{array}$ & $\begin{array}{l}\text { Endapan } \\
\text { berwarna putih }\end{array}$ \\
\hline & & $\begin{array}{l}\text { Dragend } \\
\text { orff }\end{array}$ & $\begin{array}{l}(+) \\
\text { endapan } \\
\text { warna } \\
\text { merah } \\
\end{array}$ & $\begin{array}{l}\text { Endapan warma } \\
\text { merah }\end{array}$ \\
\hline 5 & $\begin{array}{l}\text { Steroi } \\
\text { d dan } \\
\text { Tritep } \\
\text { enoid }\end{array}$ & $\begin{array}{l}\text { As. } \\
\text { Asetat } \\
\text { anhidrat } \\
\text { dan } \\
\mathrm{H}_{2} \mathrm{SO}_{4} \\
\end{array}$ & $\begin{array}{l}\text { (+) merah, } \\
\text { ungu, biru, } \\
\text { hijau }\end{array}$ & Perubahan warna \\
\hline
\end{tabular}




\begin{tabular}{|c|c|l|l|l|}
\hline 6 & $\begin{array}{c}\text { Glikosi } \\
\text { da }\end{array}$ & $\mathrm{H}_{2} \mathrm{SO}_{4}$ & $(+)$ biru & $\begin{array}{l}\text { Warna biru atau } \\
\text { hijau (reaksi } \\
\text { Liebermann } \\
\text { Burchard) }\end{array}$ \\
\hline
\end{tabular}

saponin, alkaloid, glikosida, golongan steroid dan golongan flavonoid.

Hasil pengujian menunjukkan bahwa ekstrak brotowali mengandung senyawa golongan tanin,

\section{UJI AKTIVITAS ANTIBAKTERI METODE DIFUSI CAKRAM}

Berdasarkan hasil penelitian uji aktivitas antibakteri menunjukkan bahwa fase etil asetat menunjukkan aktivitas antibakteri terhadap bakteri Staphylococcus aureus dan Bacillus Subtillis,tidak menunjukkan aktivitas antibakteri terhadap Candida albicans. Sedangkan ekstrak etanol,fase heksan, dan fase air, tidak menunjukkan aktivitas antibakteri terhadap Staphylococcus aureus, Bacillus Subtillis dan candida albicans.

Tabel 2 Diameter Daerah Hambatan Aktivitas Antimikroba Ekstrak Batang Brotowali (Tinospora Crispa L) dengan Metode Difusi Cakram

\begin{tabular}{|c|c|c|c|c|c|c|c|}
\hline \multirow[b]{2}{*}{ NO } & \multirow[b]{2}{*}{ Ekstrak Uji 10\% } & \multirow[b]{2}{*}{ Bakteri Uji } & \multicolumn{5}{|c|}{ Diameter daerah hambat $(\mathrm{mm})$} \\
\hline & & & 1 & 2 & 3 & Rata - rata & $\begin{array}{c}\text { Streptomisin } \\
1 \%\end{array}$ \\
\hline \multirow{3}{*}{1} & \multirow{3}{*}{ Ekstrak etanol } & Staphylococcus aureus & & & & & \\
\hline & & Bacillus subtillis & - & - & - & - & - \\
\hline & & Candida albicans & - & - & - & - & - \\
\hline \multirow{3}{*}{2} & \multirow{3}{*}{ Fase etil asetat } & Staphylococcus aureus & 19,0 & 19,24 & 19,30 & 19,18 & 22,25 \\
\hline & & Bacillus subtillis & 11,25 & 11,30 & 11,34 & 11,30 & 17,20 \\
\hline & & Candlida albicans & - & - & - & - & - \\
\hline \multirow{3}{*}{3} & \multirow{3}{*}{ Fase heksan } & Staphylococcus aureus & - & - & - & - & - \\
\hline & & Bacillus subtillis & - & - & - & - & - \\
\hline & & Candida albicans & - & - & - & - & - \\
\hline \multirow{3}{*}{4} & \multirow{3}{*}{ Fase Air } & Staphylococcus aureus & - & - & - & - & - \\
\hline & & Bacillus subtillis & - & - & - & - & - \\
\hline & & Candida albicans & - & - & - & - & - \\
\hline
\end{tabular}

Tabel.3 Diameter Daerah Hambatan Aktivitas Antimikroba Ekstrak Batang Brotowali (Tinospora Crispa L) dengan Metode Difusi Cakram

\begin{tabular}{|c|c|c|c|c|c|c|c|}
\hline \multirow[b]{2}{*}{ NO } & \multirow[b]{2}{*}{ Ekstrak Uji 5\% } & \multirow[b]{2}{*}{ Bakteri Uji } & \multicolumn{5}{|c|}{ Diameter daerah hambat $(\mathrm{mm})$} \\
\hline & & & 1 & 2 & 3 & Rata - rata & $\begin{array}{c}\text { Streptomisin } \\
0,5 \%\end{array}$ \\
\hline \multirow{3}{*}{1} & \multirow{3}{*}{ Ekstrak etanol } & Staphylococcus aureus & - & - & - & - & \\
\hline & & Bacillus subtillis & - & - & - & - & \\
\hline & & Candida albicans & - & - & - & - & \\
\hline \multirow{3}{*}{2} & \multirow{3}{*}{ Fase Etil Asetat } & Staphylococcus aureus & 17,3 & 17,35 & 17,45 & 17,34 & 17,45 \\
\hline & & Bacillus subtillis & 9,56 & 9,54 & 9,51 & 9,54 & 14,51 \\
\hline & & Candida albicans & - & - & - & - & - \\
\hline \multirow{3}{*}{3} & \multirow{3}{*}{ Fase $n$-heksan } & Staphylococcus aureus & - & - & - & - & - \\
\hline & & Bacillus subtillis & - & - & - & - & - \\
\hline & & Candida albicans & - & - & - & - & - \\
\hline \multirow[b]{3}{*}{4} & \multirow[b]{3}{*}{ Fase Air } & Staphylococcus aureus & - & - & - & - & - \\
\hline & & Bacillus subtillis & - & - & - & - & - \\
\hline & & Candida albicans & - & - & - & - & - \\
\hline
\end{tabular}

Tabel 4 Diameter Daerah Hambatan Aktivitas antimikroba ekstrak batang brotowali (Tinospora crispa L) dengan metode difusi cakram

\begin{tabular}{|c|c|c|c|c|c|c|c|}
\hline \multirow{2}{*}{ NO } & \multirow{2}{*}{$\begin{array}{c}\text { Ekstrak } \\
\text { Uji } \\
2,5 \%\end{array}$} & \multirow{2}{*}{$\begin{array}{l}\text { Bakteri } \\
\text { Uji }\end{array}$} & \multicolumn{5}{|c|}{$\begin{array}{l}\text { Diameter daerah hambat } \\
(\mathrm{mm})\end{array}$} \\
\hline & & & 1 & 2 & 3 & Rata-rata & $\begin{array}{c}\text { Streptomisin } \\
0,25 \%\end{array}$ \\
\hline \multirow{3}{*}{1} & \multirow{3}{*}{ Ekstrak Etanol } & Staphylococcus aureus & - & - & - & - & - \\
\hline & & Bacillus subtillis & - & - & - & - & - \\
\hline & & Candida albicans & - & - & - & - & - \\
\hline \multirow{3}{*}{2} & \multirow{3}{*}{ Fase Etil asetat } & Staphylococcus aureus & 16,58 & 16,55 & 16,51 & 16,55 & 16,60 \\
\hline & & Bacillus subtillis & 9,56 & 9,54 & 9,51 & 9,54 & 19,39 \\
\hline & & Candida albicans & - & - & - & -- & - \\
\hline \multirow{3}{*}{3} & \multirow{3}{*}{ Fase $n$-heksan } & Staphylococcus aureus & - & - & - & - & - \\
\hline & & Bacillus subtillis & - & - & - & - & - \\
\hline & & Caandida albicans & - & - & - & - & - \\
\hline
\end{tabular}




\begin{tabular}{|l|l|c|c|c|c|c|c|}
\hline \multirow{3}{*}{4} & \multirow{3}{*}{ Fase Air } & Staphylococcus aureus & - & - & - & - & - \\
\cline { 3 - 8 } & & Bacillus subtillis & - & - & - & - & - \\
\cline { 3 - 8 } & & Caandida albicans & - & - & - & - & - \\
\hline
\end{tabular}

Tabel.5 Diameter Daerah Hambatan Aktivitas antimikroba ekstrak batang brotowali (Tinospora crispa L) dengan metode difusi cakram

\begin{tabular}{|c|c|c|c|c|c|c|c|}
\hline \multirow[b]{2}{*}{ NO } & \multirow[b]{2}{*}{$\begin{array}{c}\text { Ekstrak } \\
\text { Uji } \\
1,25 \%\end{array}$} & \multirow[b]{2}{*}{$\begin{array}{c}\text { Bakteri } \\
\text { Uji }\end{array}$} & \multicolumn{5}{|c|}{$\begin{array}{l}\text { Diameter daerah hambat } \\
(\mathrm{mm})\end{array}$} \\
\hline & & & 1 & 2 & 3 & Rata-rata & $\begin{array}{c}\text { Streptomisin } \\
0,125 \%\end{array}$ \\
\hline \multirow{3}{*}{1} & \multirow{3}{*}{ Ekstrak Etanol } & Staphylococcus aureus & - & - & - & - & - \\
\hline & & Bacillus subtillis & - & - & - & - & - \\
\hline & & Candida albicans & - & - & - & - & - \\
\hline \multirow{3}{*}{2} & \multirow{3}{*}{ Fase Etil asetat } & Staphylococcus aureus & 14,60 & 14,58 & 14,50 & 14,56 & 14,60 \\
\hline & & Bacillus subtillis & 7,56 & 7,54 & 7,51 & 7,54 & 14,39 \\
\hline & & Candida albicans & - & - & - & -- & - \\
\hline \multirow{3}{*}{3} & \multirow{3}{*}{ Fase $n$-heksan } & Staphylococcus aureus & - & - & - & - & - \\
\hline & & Bacillus subtillis & - & - & - & - & - \\
\hline & & Caandida albicans & - & - & - & - & - \\
\hline \multirow{3}{*}{4} & \multirow{3}{*}{ Fase Air } & Staphylococcus aureus & - & - & - & - & - \\
\hline & & Bacillus subtillis & - & - & - & - & - \\
\hline & & Caandida albicans & - & - & - & - & - \\
\hline
\end{tabular}

Hasil pengukuran daerah daya hambat dari ekstrak etanol batang brotowali, fase $n$-heksan, fase etil asetat,dan fase air, menunjukan bahwa ekstrak etil asetat pada konsentrasi 10\%, 5\%, 2,5\%, 1,25\% mempunyai aktivitas anti bakteri terhadap staphylococcus aureus dan Bacillus subtillis, tidak menunjukkan aktivitas antibakteri terhadap Candida albicans. Ekstrak etanol, fase heksan, dan fase air tidak menunjukkan adanya hambatan (aktivitas antibakteri). Ekstrak etil asetat batang brotowali pada konsentrasi 10\% menunjukkan diameter daerah hambat terhadap bakteri Staphylococcus aureus dengan tiga kali pengulangan 19,18 mm, Bacillus subtillis $11,30 \mathrm{~mm}$, pada konsentrasi $5 \%$ menunjukkan diameter daerah hambat terhadap bakteri Staphylococcus aureus dengan tiga kali pengulangan (17,34mm), Bacillus subtillis $(9,54 \mathrm{~mm})$,pada konsentrasi $2,5 \%$ menunjukkan diameter daerah hambat terhadap bakteri Staphylococcus aureus dengan tga kali pengulangan(16,55mm), bacillus subtillis (9,54 mm), dan pada konsentrasi terendah 1,25\% menunjukkan diameter daerah hambat terhadap bakteri staphylococcus aureus dengan tiga kali pengulangan(14,56mm), bacillus subtillis $(7,54 \mathrm{~mm})$. Sedangkan terhadap Candida albicans, fase etil asetat tidak menunjukan adanya diameter daerah hambat. Pada ekstrak etanol, fase $n$ heksan, dan fase air, tidak menunjukan adanya hambatan terhadap ketiga bakteri uji.

\section{UJI BIOAUTOGRAFI}

Dengan mencoba berbagai konsentrasi cairan pengembang $n$-heksan:etil asetat (10:1, 5:1 dan 2:1), KLT dengan eluen $n$-heksan : etil asetat (5:1) merupakan eluen terbaik menghasilkan 4 bercak dan terjadi hambatan pada hRf 42,8 .

\section{IDENTIFIKASI SENYAWA KIMIA AKTIF EKSTRAK $n$-HEKSAN BATANG BROTOWALI (TINOSPORA CRISPA L) DENGAN KROMATOGRAFI GAS-SPEKTROMETRI MASSA(GCMS)}

Identifikasi dengan kromatografi gas-spektrometri massa (GCMS), dilakukan terhadap ekstrak fase etil asetat pada uji aktivitas antimikroba, setiap senyawa hasil pemisahan dianalisa lebih lanjut untuk mengetahui berat molekul dan spektra fragmentasinya, selanjutnya dibandingkan dengan spektra fragmentasi senyawa yang terdapat dalam sistem data base WILEY serta dipilih senyawa yang memiliki kemiripan lebih besar atau sama dengan 90\% dapat dilihat pada Gambar . 1 


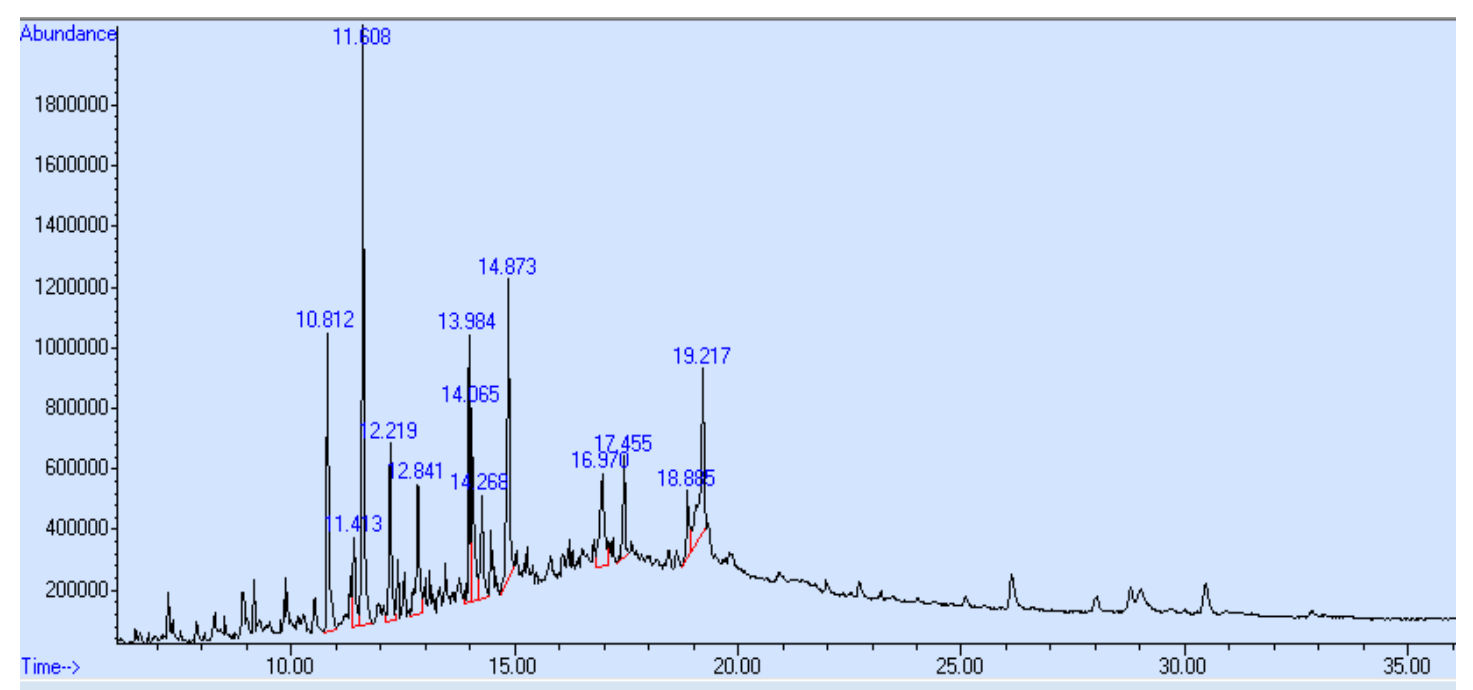

Gambar.1 Pola Total Kromatogram Ekstrak Etil Asetat Batang Brotowali.

Kromatogram ekstrak etil asetat menunjukan adanya puncak (peak) dengan waktu retensi 8,300, 10,814, 11,602, 14,871, dan 16,966. Hasil analisa puncak kromatogram masing - masing dengan GCMS menunjukan bahwa ekstrak fase etil asetat mengandung beberapa senyawa yang dapat dilihat pada Tabel .6 dengan spektrum pragmentasi masing - masing senyawa pada lampiran.

Tabel.6 Hasil Identifikasi Kromatogram dengan GCMS Ekstrak Fase Etil Asetat Batang Brotowali

\begin{tabular}{|c|c|c|c|c|c|}
\hline No & $\begin{array}{c}\text { RT } \\
\text { (menit) }\end{array}$ & Kemungkinan senyawa & Rumus molekul & $\begin{array}{c}\text { Berat molekul } \\
\text { Kemiripan } \\
(\%)\end{array}$ \\
\hline 1 & 8,300 & Octanoic acid (CAS) \$\$ Caprylic acid & C8H16O2 & 144.12 & 96 \\
\hline 2 & 10,814 & $\begin{array}{c}\text { Benzaldehyde, 4-hydroxy-3-methoxy- (CAS) } \\
\$ \$ \text { Vanillin \$\$ }\end{array}$ & C8H8O3 & 152.05 & 93 \\
\hline 3 & 11,602 & Phenol, 2,4-bis(1,1-dimethylethyl)- \$\$ & C14H22O & 206.17 & 95 \\
\hline 4 & 14,871 & Hexadecanoic acid (CAS) \$\$ Palmitic acid \$\$ & C16H32O2 & 256.24 & 99 \\
\hline 5 & 16,966 & Phenol, 4,4'-(1-methylethylidene)bis- \$\$ & C15H16O2 & 228.12 & 96 \\
\hline
\end{tabular}




\section{Identifikasi senyawa kimia aktif ekstrak etil asetat batang brotowali (Tinospora crispa L)}

dengan spektrofotometri infra merah.

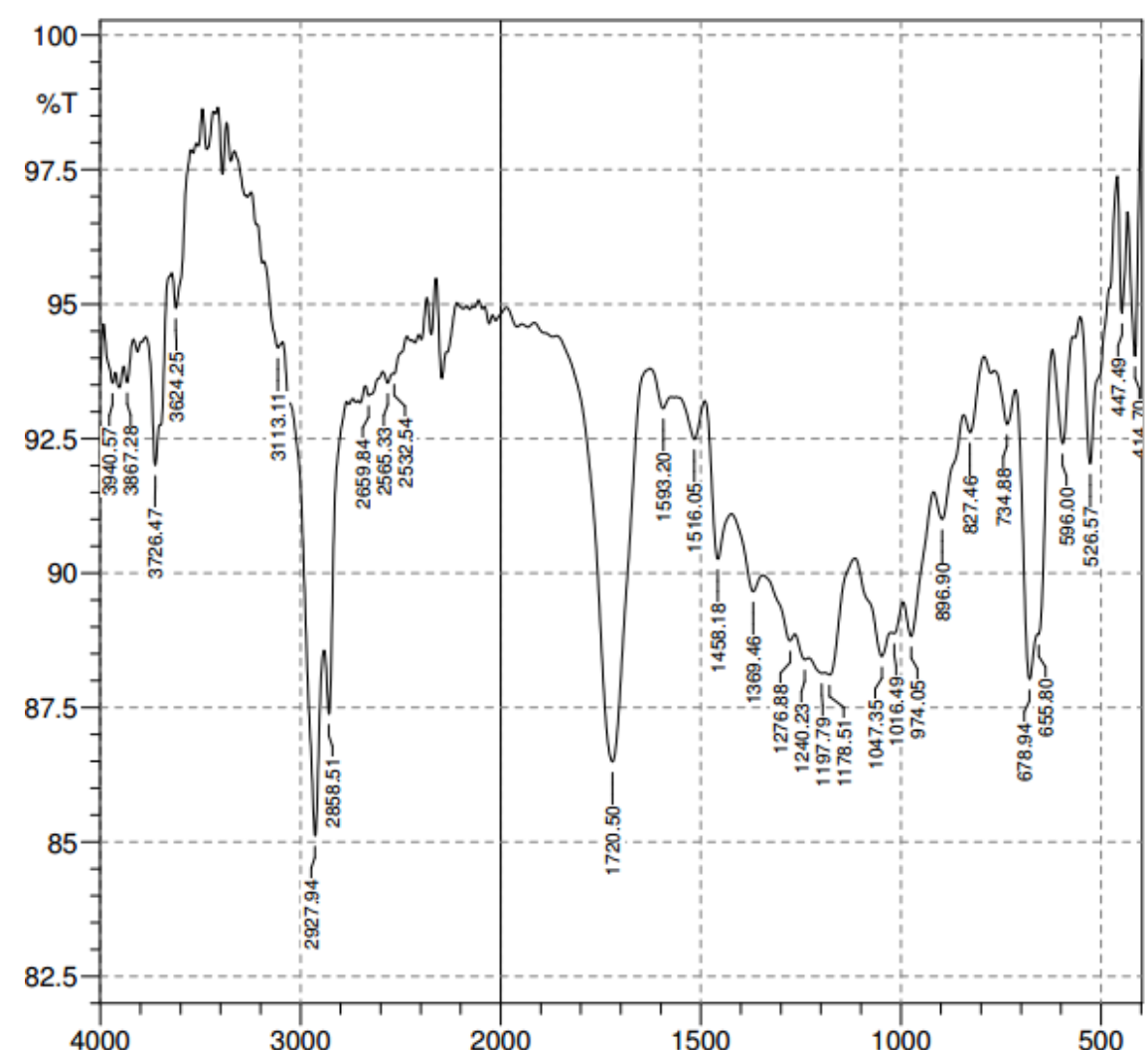

Gambar 2. Hasil Analisa Gugus Fungsi Ekstrak Etil Asetat dengan Spekrofotometri Infra Merah

Hasil analisa spektrofotometri infra red terhadap ekstrak fase etil asetat menunjukan adanya gugus - gugus fungsi $\mathrm{O}-\mathrm{H}(2400-3400 \mathrm{~cm}-1)$, gugus alkena $\mathrm{C}=\mathrm{C}(3000 \mathrm{~cm}-1), \mathrm{C}=\mathrm{O}$ strong $(1660-1820$ $\mathrm{cm}-1$ ). Analisa Infra merah ini sesuai dengan analisis yang diperoleh dari GCMS, bahwa adanya gugus $\mathrm{OH}$ dari fenol, dan adanya gugus karboksilat asam heksadekanoat dan asam palmitat ditandai dengan adanya karbonil $\mathrm{C}=\mathrm{O}$ strong $(1660-1820 \mathrm{~cm}-1)$ dan gugus fungsi $\mathrm{OH}(2400-3400$ $\mathrm{cm}-1)$.

\section{KESIMPULAN}

1. Hasil uji aktivitas antimikroba terhadap ekstrak batang brotowali menunjukkan bahwa fase $n$-heksan yang paling aktif terhadap staphylococcus aureus dan bacillus subtillis.

2. Eluen Kromatografi Lapis Tipis $(K L T)$ yang paling baik dalam pemisahan kromatogram adalah $n$-heksan : etil astetat dengan perbandingan $5: 1$.

3. Hasil identifikasi spektrofotometri infra red (IR) dan kromatografi gas-spektrometri massa (GCMS) senyawa kimia sebagai antimikroba adalah gugus-gugus fungsional $\mathrm{CO}, \mathrm{CH}$ stretch, alkena $(\mathrm{C}=\mathrm{C}), \mathrm{OH}$ dan senyawa Hexadecanoic Palmitic acid dan Bezaldehyd, 4-

\section{SARAN} hydroxy 3 methoxy vanillin.

1. Aktivitas anti mikroba batang brotowali perlu diuji secara in vivo pada hewan percobaan.

2. Perlu penelitian lebih lanjut untuk menentukan struktur kimia dengan pengambilan data spektro RMI proton dan karbon.

\section{DAFTAR PUSTAKA}

1. Hadad M., Widayanti, S.M., Brotowali (Tinospora crispa (L) F Hook and Thoms), dalam Tumbuhan Obat Indonesia (Pengguna dan Khasiatnya). Pustaka Obor. Jakarta. 2001.

2. Kardono LBS. Mono graphs and Description Selected, Indonesian Medicinal Plant. h 98 - 103

3.Kusumaningtyas E, Astuti E, Darmono Sensitivitas metode bioautografi kontak dan agar overlay dalam penentuan senyawa anti kapang, Jurnal Ilmu Kefarmasian Indonesia, 2008 h75-9

4. Harbone JB. Metode Fitokimia. Edisi 2. Dterjemahkan oleh Padmawinata K, Sudiro I Bambang ITB; 1987. h 40, $69-147,234,283$

5. Henry. Clinical Microbiology Procedures Handbook vol.1 American Society For Microbiology, Washington DC ; 1992. h 35-67 
33 